\title{
Innsatspersonell fikk større tro på egen mestring etter terrorangrepene 22. juli 2011
}

\author{
FAGFELLEVURDERT FORSKNING
}

PUBLISERT: 29.06.2018 | OPPDATERT: 02.07.2018

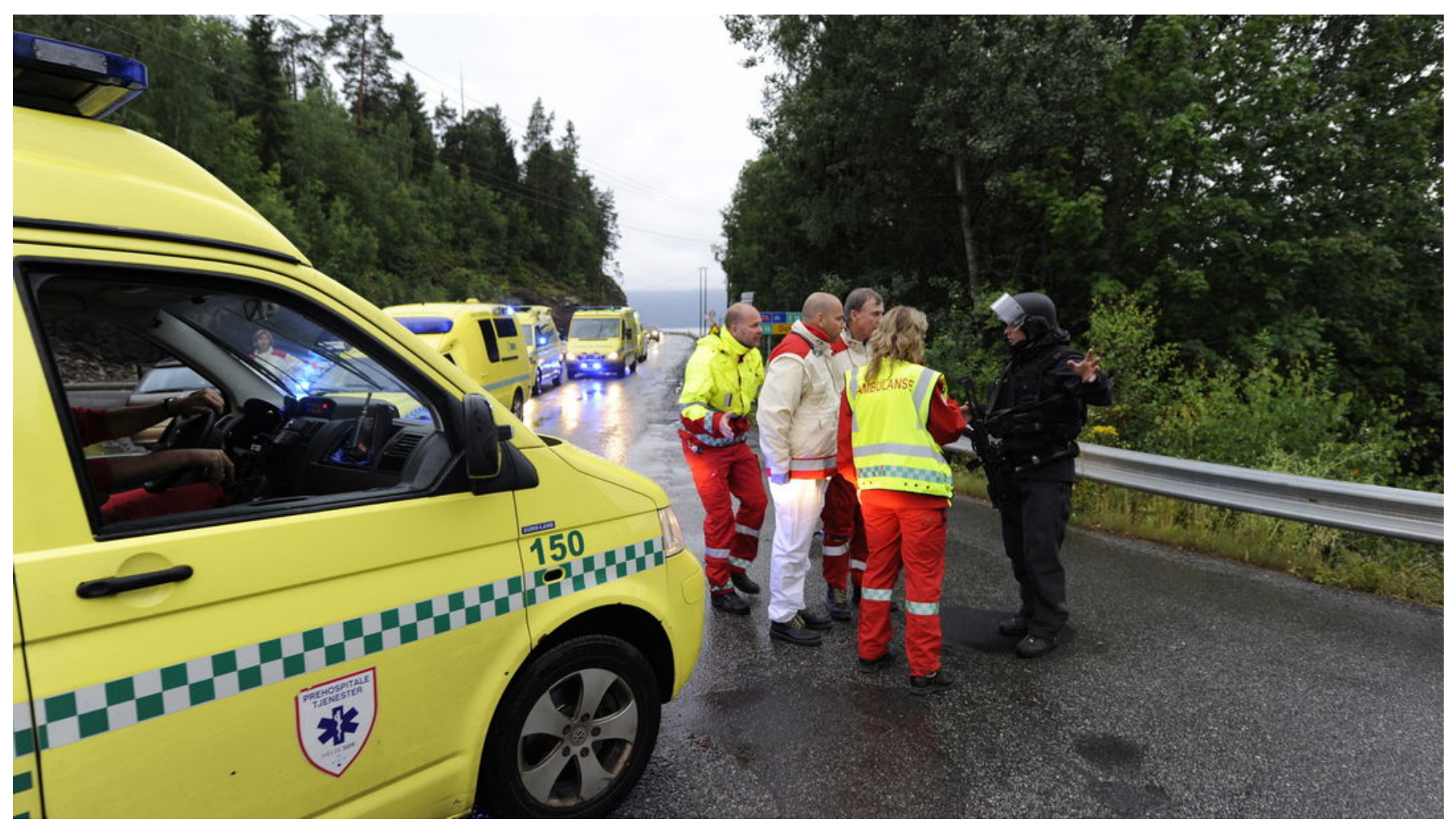

MESTRING: Det profesjonelle innsatspersonellet har hatt lav forekomst av posttraumatisk stresslidelse etter redningsarbeidet i regjeringskvartalet og på Utøya. På bildet koordineres hjelpearbeidet ved Utøya. (Illustrasjonsfoto: Morten Edvardsen / NTB scanpix)

\section{FORFATTERE}

\section{Laila Skogstad}

Førsteamanuensis og postdoktor

Fakultet for helsefag - paramedic, Oslomet - storbyuniversitetet og Akuttmedisinsk avdeling, Oslo Universitetssykehus, Ullevål

\section{Therese Brask-Rustad}

Psykologspesialist

Drammen psykiatriske senter, Vestre Viken

\section{Bjørn Rishovd Rund}


Forskningsdirektør og professor

Vestre Viken og Psykologisk institutt, Universitetet i Oslo

\section{Øivind Ekeberg}

Spesialrådgiver og professor emeritus

Klinikk psykisk helse og avhengighet, Oslo universitetssykehus Ullevål og Avdeling for medisinsk

atferdsvitenskap, Institutt for medisinske basalfag, Medisinsk fakultet, Universitetet i Oslo

\section{Nøkkelord}

Atferd Beredskap Helsepersonell Katastrofemedisin Stress

\section{Helsepersonell, politi, brann- og redningsetaten samt organiserte frivillige opplevde støtte fra ledelsen, godt samarbeid og stolthet over innsatsen.}

\section{SAMMENDRAG}

Bakgrunn: Deltakelsen i redningsarbeidet etter terrorhandlingene 22. juli 2011 var krevende, uvant og uforutsigbart. Arbeid knyttet til større hendelser kan være belastende, men også gi økt opplevelse av vekst. Det er imidlertid få studier som er knyttet til opplevelsen av å få større tillit til utøvelsen av egen innsats.

Hensikt: Å undersøke i hvilken grad innsatspersonell er mer forberedt på å mestre liknende situasjoner i fremtiden. Vi ønsket også å finne ut hvilke faktorer som er forbundet med bedre mestringsopplevelse.

Metode: Ti måneder etter terrorhandlingene 22. juli 2011 deltok helsepersonell, politi, brann- og redningsetaten og organiserte frivillige i en tverrsnittsundersøkelse om faglige utfordringer, opplevd støtte og personlige reaksjoner etter hendelsene. Kvalitative data utdyper resultatene.

Resultat: Svarprosenten var 62 (1734/2801). Alle gruppene rapporterte at de var mer forberedt på å mestre liknende situasjoner i fremtiden (gjennomsnittsverdi 3,5-3,7; skala 1-5). Tidlig oppstart av arbeidet (OR 1,5, KI 1,2-1,9), flere vitneopplevelser (OR 1,5, KI 1,2-1,9) og høyere grad av rolleklarhet $(\mathrm{OR} 1,5, \mathrm{KI} 1,2-1,9)$ var forbundet med $\varnothing \mathrm{kt}$ opplevelse av mestring. Sammenliknet med personer som var yngre enn 30 år, var det lavere mestringsopplevelse i aldersgruppen 30-49 år (OR 0,7, KI 0,5-0,9 $(p=0,05)$ og aldersgruppen 50 år eller eldre (OR 0,5, KI 0,3-0,7, p<0,001).

Konklusjon: Virkelige hendelser gir en læringsmulighet man ikke kan oppnå teoretisk eller ved øvelser. Større belastning var forbundet med $\varnothing \mathrm{kt}$ mestringsopplevelse. Omsorgsfull ledelse samt en opplevelse av samarbeid og stolthet knyttet til innsatsen kan også ha bidratt til økt mestringsfølelse.

22. juli 2011 ble Norge rammet av den største terrorhandlingen siden andre verdenskrig. Åtte personer ble drept og ti innlagt på sykehus etter bombingen av regjeringskvartalet i Oslo. Omtrent 325 mennesker var i umiddelbar nærhet av bomben. På Utøya drepte gjerningsmannen 69 personer. Der deltok 564 mennesker på sommerleir, og omtrent halvparten av dem ble skadet (1). 
Under de kaotiske forholdene opplevde mange av innsatspersonellet at de også var i fare, på grunn av brann, ras av bygningsmasse og frykt for flere bomber. Ved Utøya opplevde innsatspersonellet at det ble skutt mot dem.

Tidligere unders $\varnothing$ kelser av innsatspersonell har påvist sammenheng mellom alvorlige ulykker, katastrofer og forekomst av posttraumatisk stresslidelse (PTSD, post-traumatic stress disorder) eller posttraumatisk stressymptomer (PTSS, post-traumatic stress syndrome) (2-5). Forekomsten av PTSD varierer fra 2 til 21 prosent.

Etter terrorhandlingene i Norge fant vi lav forekomst ( 0,3 prosent) av mulig PTSD blant det profesjonelle innsatspersonellet (6). Sykefraværet utover to uker samt behovet for psykologisk hjelp var også lavt (7).

\section{Tidligere forskning}

Det er forsket på personlig vekst som resultat av å løse krevende nye utfordringer og oppgaver i forbindelse med en traumatisk hendelse (8, 9). Slik vekst blir ofte kalt posttraumatisk vekst (8). Unders $\varnothing$ kelser av psykososialt personell som skal bistå mennesker i kriser, viser også personlig vekst (10). Det samme er funnet blant brannmenn etter større branner (11), og hos politiet ved alvorlig voldskriminalitet (12).

I en studie av innsatspersonell etter tsunamien i Sørøst-Asia i 2004 fant Thoresen (13) at trening, erfaring og forberedelse før oppdraget samt organisatorisk st $\varnothing t t e$ hadde sammenheng med en opplevelse av bedre mestring. Liknende funn er fremkommet for innsatspersonell som politi, brannmenn og ambulansepersonell samt sykepleiere i intensivavdelinger på sykehus (14).

Studier av vekst omfatter svært ulike hendelser og har forskjellige mål. Arbeidet i forbindelse med terrorhandlingene i Norge var spesielt fordi innsatspersonellet sto overfor en særdeles destruktiv og uoversiktlig situasjon.

\section{Hensikten med studien}

Terrorhandlinger er et $\varnothing$ kende fenomen i den vestlige verden, og det er krevende og uforutsigbart å delta i redningsarbeidet. Men slikt arbeid kan også gi muligheter for læring som innsatspersonell ikke kan oppnå ved øvelser.

Vi har tidligere funnet at graden av forberedelse - som trening, erfaring og øvelse - hadde sammenheng med rolleklarhet (15). I den delen av studien unders $\varnothing$ kte vi i hvilken grad tidligere erfaringer påvirket funksjon og mestring under innsatsarbeidet. I denne artikkelen unders $\varnothing$ ker vi om innsatspersonellet har opplevd at innsatsarbeidet førte til utvikling og vekst.

\section{«Slikt arbeid kan også gi muligheter for læring som innsatspersonell ikke kan oppnå ved øvelser.»}


Vi unders $\varnothing$ kte derfor følgende problemstillinger:

- I hvilken grad er innsatspersonell forberedt på å mestre liknende situasjoner i fremtiden?

- Hvilke faktorer er forbundet med bedre mestringsopplevelse?

\section{Metode}

Vi gjennomførte en kvantitativ tverrsnittsunders $\varnothing$ kelse cirka ti måneder etter hendelsen. I tillegg til spørsmål med svaralternativer hadde vi en åpen rubrikk med overskriften «Kommentarer». Vi $\emptyset$ nsket å analysere mulige forklaringer på fremtidig mestring som ikke kom frem i de kvantitative dataene. Kommentarene fra helsepersonell ble samlet etter tema. Vi har ikke foretatt noen systematisk kvalitativ analyse, men har valgt ut noen kommentarer som har gått igjen, og som illustrerer de kvantitative funnene.

Inklusjonskriteriet var å ha deltatt i rednings- og oppfølgingsarbeidet fra 22. juli og de to påfølgende ukene. Lederne i avdelinger som deltok i rednings- og oppfølgingsarbeidet, hadde ansvaret for å identifisere personell samt dele ut og samle inn spørreskjemaene via nettskytjenesten Dropbox eller i lukkede konvolutter.

Personellet fikk en påminnelse etter en måned. Vi kan ikke redegjøre for dem som ikke responderte, da det var lederne som distribuerte spørreskjemaet, og svarene var anonyme. Vi har ikke foretatt styrkeberegning da vi inviterte alle som deltok i arbeidet.

Denne studien er en del av en større undersøkelse. Metoden er beskrevet mer detaljert i en tidligere publisert artikkel (6).

\section{Spørreskjema}

Vi utformet spørreskjemaet blant annet med bakgrunn i en spørreunders $\varnothing$ kelse som ble gjennomført med innsatspersonell etter tsunamien i Sørøst-Asia i 2004 (13). I tillegg utformet vi noen spørsmål om hendelsene 22. juli 2011.

\section{Deltakere}

Aldersmessig ble deltakerne delt inn i gruppene <30 år, 30-49 år og >50 år. Vi ønsket å vite hvor respondentene i hovedsak arbeidet og hadde derfor skadestedene regjeringskvartalet og Utøya eller andre arbeidssteder, som sykehus, senter for pårørende og overlevende, legevakt, kontor eller patruljering, som svaralternativer. Vi ønsket også å vite når arbeidet startet. Oppstart av arbeidet ble dikotomisert til a) 23. juli og senere, og b) 22. juli.

Fra helsevesenet deltok a) medisinsk helsepersonell (lege, sykepleier, annet helsepersonell, ambulansearbeidere, AMK-personell), b) psykososialt helsepersonell (lege, sykepleier, psykolog, annet helsepersonell, prest eller sjelesørger, sosionom). Fra politiet deltok operativt personell og personell med kontoroppgaver, og fra brann- og redningsetaten deltok brann- og redningspersonell samt dykkere. 
I tillegg inkluderte vi ulike grupper organiserte frivillige eller forsvaret (Sivilforsvaret, Heimevernet, Norsk Folkehjelp og Norske Redningshunder). Vi spurte også om de hadde erfaring fra hendelser med $>5$ omkomne, med svaralternativet «nei/ja».

Tilfeldig frivillige ved Utøya deltok også i redningsarbeidet, men disse ble ikke inkludert i denne artikkelen fordi målgruppen var profesjonelt innsatspersonell.

\section{Eksponering}

Opplevd frykt for eksplosjon eller skyting ble målt med følgende svaralternativer: a) «Nei, har ikke opplevd», b) «Ja, var ikke/lite belastende», c) «Ja, var moderat belastende», og d) «Ja, var svært belastende».

Svaralternativ b, c, og d ble slått sammen da få svarte at det hadde vært moderat eller svært belastende, og en dikotom variabel var derfor mer hensiktsmessig å benytte i analysen.

Eksponering for inntrykk ble målt med antall vitneopplevelser. I utgangspunktet svarte deltakerne på sju spørsmål om mulige vitneopplevelser. En faktoranalyse ga to faktorer: det å oppleve å se fortvilte, og det å se eller være i fysisk kontakt med alvorlige skadde eller døde mennesker. Dette resultatet er vist i en annen artikkel (6).

I denne artikkelen er variabelen vitneopplevelse benyttet. I denne er total belastning og resultat fra de sju spørsmålene slått sammen og dikotomisert på bakgrunn av medianverdien 1 til verdien «O = ikke opplevd / få» og «1 = har opplevd flere». Spørsmål om verbal utskjelling eller trakassering ble på tilsvarende måte summert og dikotomisert ( $« 0=$ ikke opplevd», «1 = har opplevd». Få rapporterte å ha opplevd utskjelling eller trakassering som moderat eller svært belastende.

\section{Organisatoriske forhold}

Rolleklarhet ble belyst med spørsmålet «Visste du hva som var ditt ansvarsområde?», med svaralternativene fra $\ll 1=$ ikke i det hele tatt» til «5 = i meget høy grad».

Vi klassifiserte støttetiltak fra arbeidsgiver med følgende alternativer: møter som defusing/debrifing, møter som markerte overganger, egen fagperson som psykolog osv., middager eller andre samlinger, og annet. De ble slått sammen og dikotomisert til «nei/ja». Vi ønsket å se på den totale mengden iverksatte støttetiltak.

Utfallsvariabelen mestring ble kartlagt ved hjelp av følgende spørsmål:

- I hvilken grad er du mer forberedt på å mestre liknende situasjoner etter 22. juli 2011 ?

Vi benyttet svaralternativer på en femdelt Likert-skala, der «1 = ikke i det hele tatt» og «5 = i meget høy grad». 


\section{Statistikk}

Deskriptive data er presentert som gjennomsnittsverdier med 95 prosent konfidensintervall (KI) eller med antall og prosentandel. Det var generelt få manglende data på spørsmålene $\left(0,4^{-1,7}\right.$ prosent). Vi benyttet kjikvadrat og Kruskal-Wallis for å sammenlikne kategoriske variabler, og ANOVA for å sammenlikne gjennomsnitt i normalfordelte variabler.

For å korrigere for mange analyser foretok vi Bonferroni-korreksjon. For å identifisere uavhengige sammenhenger med resultatmålet mestring ble variabler med en bivariat $\mathrm{p}$-verdi $<0,10$ lagt inn $\mathrm{i}$ en multivariat logistisk regresjon (enter). Vi benyttet ujustert og justert odds ratio (OR) og 95 prosent KI fra logistisk regresjonsanalyse med tilhørende signifikansverdi. Vi benyttet SPSS versjon 21.0. Signifikansnivået ble satt til $\mathrm{p}<0,05$.

\section{Etikk}

Alle dataene ble samlet inn anonymt. Derfor ble purringen sendt til alle som hadde fått skjemaet ved første utsendelse. Undersøkelsen ble godkjent av personvernombudet ved Oslo universitetssykehus, med beskjed om at godkjenning fra Regionale komiteer for medisinsk og helsefaglig forskningsetikk (REK) ikke var påkrevd. Vi lagret dataene på forskningsserveren ved Oslo universitetssykehus.

\section{Resultater}

I alt sendte vi ut 2801 spørreskjemaer og fikk i retur 1734 skjemaer (62 prosent). Svarprosenten varierte fra 82 for brann- og redningsetaten til 51 for organiserte frivillige (figur 1). 
Figur 1. Innsatspersonell som ble invitert til å delta i studien $(n=2801)$

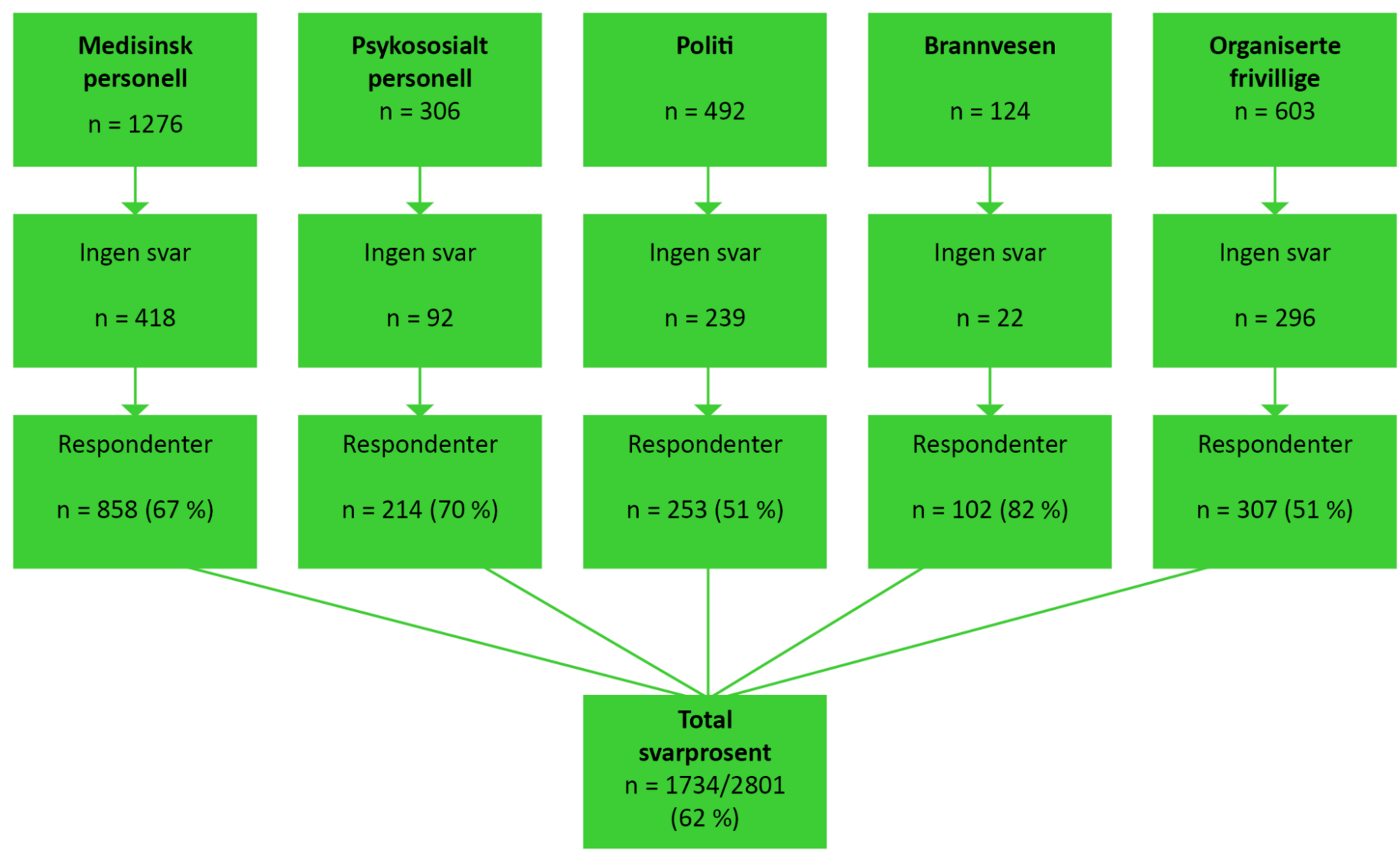

16 prosent av det medisinske personellet jobbet på skadestedene. Til sammenlikning jobbet ingen av det psykososiale personellet der, men 97 prosent fra brann- og redningsetaten. De fleste innen medisinsk personell, politi og brann- og redningsetaten startet innsatsen 22. juli. Rundt 25 prosent av personellet $\mathrm{i}$ alle gruppene, bortsett fra organiserte frivillige (9 prosent), rapporterte å ha erfaring med ulykker der flere enn fem omkom (tabell 1). 
Tabell 1. Bakgrunnsfaktorer for kjønn, alder, arbeidsforhold og erfaring

\begin{tabular}{|c|c|c|c|c|c|}
\hline & $\begin{array}{l}\text { Medisinsk } \\
\text { personell }\end{array}$ & $\begin{array}{l}\text { Psykososialt } \\
\text { personell }\end{array}$ & Politi & Brannvesen & $\begin{array}{l}\text { Organiserte } \\
\text { frivillige }\end{array}$ \\
\hline n (\%) & $\mathrm{n}=858$ & $\mathrm{n}=214$ & $\mathrm{n}=253$ & $\mathrm{n}=102$ & $\mathrm{n}=313$ \\
\hline Kjønn, Mann & $283(33,1)$ & $73(34,1)$ & $170(68,0)$ & $100(99,0)$ & $238(77,5)$ \\
\hline \multicolumn{6}{|l|}{ Alder } \\
\hline$<30$ år & $158(18,5)$ & $18(8,5)$ & $29(11,6)$ & $11(10,8)$ & $67(21,8)$ \\
\hline 30-49 år & $534(62,5)$ & $90(42,3)$ & $172(68,8)$ & $68(66,7)$ & $193(62,9)$ \\
\hline$>50$ år & $162(19,0)$ & $105(49,3)$ & $49(19,6)$ & $23(22,5)$ & $47(15,3)$ \\
\hline \multicolumn{6}{|l|}{ Arbeidssted 22. juli } \\
\hline $\begin{array}{l}\text { Skadestedene (regjerings- } \\
\text { kvartalet, Utøya) }\end{array}$ & $138(16,3)$ & $0(0)$ & $92(36,8)$ & $99(97,1)$ & $170(55,4)$ \\
\hline Annet & $710(83,7)$ & $214(100)$ & $158(63,2)$ & $3(2,9)$ & $137(44,6)$ \\
\hline \multicolumn{6}{|l|}{ Oppstart av arbeid } \\
\hline 23. juli eller senere & $155(18,1)$ & $103(48,1)$ & $51(20,2)$ & $26(25,7)$ & $156(50,8)$ \\
\hline 22. juli & $699(81,9)$ & $111(51,9)$ & $201(79,8)$ & $75(74,3)$ & $151(49,2)$ \\
\hline $\begin{array}{l}\text { Erfaring fra ulykke med } \\
>5 \text { omkomne, Ja }\end{array}$ & $210(24,7)$ & $58(27,4)$ & $67(26,6)$ & $31(30,4)$ & $27(8,8)$ \\
\hline
\end{tabular}

En høyere andel i politiet (50 prosent) og brann- og redningsetaten (62 prosent) rapporterte å ha opplevd frykt for eksplosjon eller skyting sammenliknet med psykososialt personell (14 prosent), $\mathrm{p}<0,001$ (tabell 2). Brannmenn rapporterte også å ha hatt signifikant flere vitneopplevelser enn de andre gruppene, henholdsvis 85 prosent kontra 28 prosent for psykososialt personell og 43 prosent for politi.

Tabell 2. Eksponering for ytre potensielle stressfaktorer

\begin{tabular}{llllll} 
& $\begin{array}{l}\text { Medisinsk } \\
\text { personell } \\
\mathrm{n}=858\end{array}$ & $\begin{array}{l}\text { Psykososialt } \\
\text { personell } \\
\mathrm{n}=214\end{array}$ & Politi & Brannvesen & $\begin{array}{l}\text { Organiserte } \\
\text { frivillige } \\
\mathrm{n}=313\end{array}$ \\
\hline $\begin{array}{l}\text { Frykt for eksplosjon/ } \\
\text { skyting, Ja, } \mathrm{n}(\%)\end{array}$ & $287(34,1)$ & $30(14,5)$ & $123(50,0)$ & $63(62,4)$ & $99(32,7)$ \\
$\begin{array}{l}\text { Vitneopplevelser } \\
\text { Få vitneopplevelser }\end{array}$ & $404(47,8)$ & $151(71,6)$ & $140(56,5)$ & $15(14,7)$ & $210(69,5)$ \\
$\begin{array}{l}\text { Flere vitneopplevelser } \\
442(52,2)\end{array}$ & $60(28,4)$ & $108(43,5)$ & $87(85,3)$ & $92(30,5)$ \\
$\begin{array}{l}\text { Verbal utskjelling, } \\
\text { Ja, } \mathrm{n}(\%)\end{array}$ & $87(10,3)$ & $45(21,4)$ & $64(26,6)$ & $3(3,0)$ & $18(6,0)$ \\
& & & & \\
\hline
\end{tabular}

Rolleklarheten, målt med gjennomsnittsverdi (tabell 3), hadde for det meste vært tydelig i alle gruppene, men psykososialt personell (skår = 3,6, KI = 3,5-3,7) og politi (skår =3,9, KI = 3,8-4,0) 
rapporterte noe lavere gjennomsnittsverdi sammenliknet med de andre gruppene (skår = 4,2, $\mathrm{p}<$ ○,001). Spesielt i brann- og redningsetaten fikk de god st $\varnothing$ tte fra arbeidsgiveren eller oppdragsgiveren, hvor 95 prosent svarte «ja, vi har deltatt på organiserte tilbud».

Det var ingen signifikant forskjell mellom medisinsk personell, psykososialt personell og politi når det gjaldt deltakelse i støttetilbud, mens brannvesenet hadde signifikant høyere andel som deltok. Organiserte frivillige hadde signifikant lavere andel (65 prosent) enn de tre ikkesignifikante gruppene.

Tabell 3. Arbeidsrelaterte variabler

\begin{tabular}{|c|c|c|c|c|c|c|}
\hline & $\begin{array}{l}\text { Medisinsk } \\
\text { personell }\end{array}$ & $\begin{array}{l}\text { Psykososialt } \\
\text { personell }\end{array}$ & Politi & Brannvesen & $\begin{array}{l}\text { Organiserte } \\
\text { frivillige }\end{array}$ & P-verdi \\
\hline $\begin{array}{l}\text { Gjennomsnittsverdi (95\% KI) } \\
\text { eller n (\%) }\end{array}$ & $\mathrm{n}=858$ & $n=214$ & $n=253$ & $n=102$ & $n=313$ & \\
\hline Rolleklarhet, (skala 1-5)§ & $4,2(4,1-4,2)$ & $3,6(3,5-3,7)$ & $3,9(3,8-4,0)$ & $4,2(4,0-4,3)$ & $4,2(4,1-4,3)$ & $<0,001$ \\
\hline \multicolumn{7}{|l|}{ Gjennomsnittsverdi (95 \% KI) } \\
\hline $\begin{array}{l}\text { Støtte fra arbeidsgiver, Ja, } \\
\mathrm{n}(\%)\end{array}$ & $656(81,2)$ & $155(74,2)$ & $194(80,5)$ & $92(94,8)$ & $194(64,7)$ & $<0,001$ \\
\hline $\begin{array}{l}\text { Mer forberedt på å mestre } \\
\text { liknende situasjoner i frem- } \\
\text { tiden, (skala 1-5)§ }\end{array}$ & $3,6(3,6-3,7)$ & $3,6(3,5-3,7)$ & $3,6(3,5-3,7)$ & $3,5(3,3-3,6)$ & $3,7(3,6-3,8)$ & ns \\
\hline Gjennomsnittsverdi (95 \% KI) & & & & & & \\
\hline
\end{tabular}

$\S$ Skala: $1=$ ikke i det hele tatt, $5=$ i meget høy grad KI: konfidensintervall

I analysen av kommentarer gitt av helsepersonellet fant vi tre temaer som gikk igjen:

- å bli ivaretatt av lederen

- samarbeid

- opplevelse av å være stolt over egen og andres innsats

\section{Å bli ivaretatt av lederen}

En respondent svarte følgende: «Vår seksjonsleder brukte nesten hele dagen sammen med oss. Det var flott!» En annen uttrykte følgende: «Tilbudet om debrifing var til stede med én gang. Ble spurt hver dag av leder (nesten litt for mye).» Men ikke alle opplevde oppfølgingen slik, spesielt gjaldt det dem som gikk ut i ferie eller var ferdige med et vikariat, og som ikke fikk tilbud om oppfølging.

\section{Samarbeid}

Mange fremhevet samarbeidet disse dagene: «22. juli var den verste og samtidig den beste vakten jeg har hatt. Det verste sier seg selv. Det beste var måten alt fungerte på, der folk trakk i samme 
retning, både i min gruppe og tverrfaglig. Ikke noe tull og vanskeligheter.» En kommentar fra prehospital tjeneste lød som følger: «Personell i mottak Ullevål plasserte sjokolade/cola på bårer og sendte med personell ut igjen ...»

\section{«Det beste var måten alt fungerte på, der folk trakk i samme retning, både i min gruppe og tverrfaglig.»}

\section{Informant}

En respondent fra psykososialt personell skrev følgende: «Samarbeidet med somatisk helsepersonell var godt, og vi som kom fra psykiatrien, ble verdsatt.» Det kom dog frem en frustrasjon blant det somatiske personellet. Den gikk ut på manglende psykososial oppfølging av traumatiserte eller kritisk syke pasienter og deres pårørende i hverdagen. Vedkommende svarte følgende vedrørende 22. juli: «Alle støttefunksjoner sa ja - mot normalt - hvor alle kjemper for å få tak i en ressurs.»

\section{Opplevelse av å være stolt over egen og andres innsats}

En respondent skrev følgende: «Det var fint å se at systemet fungerte, og den innsatsen som alle som var til stede, gjorde.» En annen skrev følgende: «Ringerike sykehus gjorde en kjempeinnsats 22. juli ... [A]lle pasienter overlevde.»

En tredje fremhevet som følger: «Jeg er stolt over at vi maktet en slik situasjon på en så profesjonell måte ... [Det var] et privilegium å få lov til å bidra som helsepersonell ... [Jeg] vil huske arbeidet med takknemlighet.» Respondentene reflekterte også rundt noen utfordringer i kommentarene.

En respondent skrev dette: «[M]aktesløsheten blant dem som ikke fikk bidra, som hadde kompetansen, men som det ikke var 'bruk for'.»

En sluttkommentar lød slik fra en respondent: «Det er selvfølgelig ønskelig at jeg i høy grad vil mestre en liknende situasjon etter 22/7, men slik vet man jo aldri. Jeg tror jeg er mer forberedt på egne reaksjoner etter hendelsen.»

Alle gruppene rapporterte om at de var mer forberedt på å mestre liknende situasjoner, men det var ingen signifikante forskjeller mellom gruppene (skår $=3,5-3,7$ ).

\section{Faktorer forbundet med opplevelsen av å mestre liknende situasjoner i fremtiden}

Fjorten variabler var ujustert forbundet med opplevelsen av å kunne mestre en liknende situasjon i fremtiden. I den multivariate justerte analysen var det noen variabler som var signifikant forbundet med å mestre liknende situasjoner i fremtiden. Sammenliknet med personer som var 
yngre enn 30 år, var det lavere mestringsopplevelse i aldersgruppen 30-49 år (OR o,7, KI o,5-0,9, $\mathrm{p}=0,05)$ og aldersgruppen 50 år eller eldre (OR o,5, KI ०,3-0,7, p < 0,००1).

Vi fant $\varnothing \mathrm{kt}$ mestringsopplevelse blant dem som startet arbeidet 22. juli sammenliknet med dem som startet senere (OR 1,5, KI 1,2-1,9, $\mathrm{p}=0,002)$. Det samme gjaldt dem som hadde hatt en eller flere vitneopplevelser (OR 1,5, KI 1,2-1,9, p = 0,002), og dem som opplevde høyere grad av rolleklarhet (OR 1,5, KI 1,2-1,9, $\mathrm{p}=0,002)$.

Sammenliknet med medisinsk personell var det $\varnothing \mathrm{kt}$ mestringsopplevelse blant psykososialt personell (OR 1,9, KI 1,3-2,7, p < 0,001), politi (OR 1,4, KI 1,O-2,O, p = 0,024) og frivillig innsatspersonell (OR 1,7, KI 1,2-2,3, p = o,०O1), men mindre for brannmenn (OR ०,6, KI ०,4-1,०, p $=0,052)$. Det var ingen signifikant forskjell mellom kvinner og menn.

\section{Diskusjon}

Alle gruppene rapporterte at de var mer forberedt på å mestre liknende situasjoner etter terrorhandlingene. Forklaringsvariablene «oppstart av arbeidet 22. juli», «flere vitneopplevelser», «høyere grad av opplevd rolleklarhet» og «yngre alder» var forbundet med større tro på fremtidig mestring.

I STAMI-rapport 3 (14) fremheves det at mestring av utfordringer kan føre til økt motstandsdyktighet. Denne antakelsen var knyttet til funn fra en studie av brannmenn, der tro på egen mestring beskyttet mot depresjon og PTSD. I samme rapport hevder Skogstad og medarbeidere at innsatspersonell, som politi og brannvesen, gjerne er selektert for jobben og trent for arbeidsoppgaver som blir utført under krevende forhold.

\section{«Alle gruppene rapporterte at de var mer forberedt på å mestre liknende situasjoner etter terrorhandlingene.»}

Respondentene i vår studie er selekterte i form av utdanning og trening for oppgaver under krevende forhold, noe som da kan støtte våre funn. Vi fant at yngre alder var forbundet med tro på mestring. Janacsek og medarbeidere (16) fant en gradvis reduksjon i reaksjonstid og observasjonsevne med $\varnothing$ kende alder (4-85 år).

En slik reduksjon gjaldt imidlertid ikke for unge voksne og middelaldrende. Det er likevel grunn til å tro at yngre innsatspersonell har mindre erfaring, og at arbeid med en katastrofe dermed vil kunne gi større læringseffekt. Man kan tenke at de utviklet nye mestringsstrategier i forbindelse med arbeidet, noe som også ble fremhevet i en studie av politiet i STAMI-rapporten (14).

Siden nivået av posttraumatiske symptomer i studien vår generelt var lavt (6), er det grunn til å anta at mestringsopplevelsen var stor, og at dette har påvirket opplevelsen av læring.

\section{Oppstartsdagen påvirket troen på mestring}


Det var sammenheng mellom $\varnothing \mathrm{kt}$ tro på fremtidig mestring og variabelen «oppstart av arbeidet 22. juli». Denne dagen var også mer krevende. Det er sannsynlig at trusler og vitneopplevelser kan overstige mestringsevnen og føre til mer posttraumatiske symptomer og mindre læring, særlig hvis det er langvarig eksponering som hindrer arbeidet.

Innsatsen 22. juli var avgrenset i tid, og de fleste rapporterte om høy grad av rolleklarhet og støtte fra arbeidsgiver. I tillegg beskrev respondenter fra helsevesenet et godt samarbeid og stolthet over innsatsen. Ovennevnte kan tyde på at det er et «vindu» hvor graden av utfordringer kan gi best læring. Overstiges den $\varnothing$ vre grensen for mestring, kan det oppleves som traumatisk. Dersom utfordringene er for små, vil det være lite å lære.

De lave skårene på posttraumatiske stressreaksjoner tyder på at denne hendelsen ikke har overskredet mestringsevnen. Selv om de fleste fra brann- og redningsetaten rapporterte om vitneopplevelse, skilte de seg ikke signifikant fra de øvrige gruppene. Det kan henge sammen med at de i stor grad hadde erfaring fra liknende oppgaver.

Vi har ikke data som kan underbygge hvorfor det ser ut til at politiet var litt mer belastet. Men utfordringene var nok noe mer uvante for dem, og de fikk også mer kritikk etterpå (1).

\section{Rolleklarhet ga mestring}

Større rolleklarhet hadde sammenheng med $\varnothing \mathrm{kt}$ mestringsfølelse i vår studie. En studie av politiet viste at arbeidsrelaterte organisatoriske forhold, blant annet liten rolleklarhet og dårlig sosialt samspill mellom kollegaer, hadde en sammenheng med PTSD (14). Særlig hvis noe går galt, kan det føre til en følelse av utilstrekkelighet og dårlig mestring.

Ressurstilgangen i etterkant av terrorhandlingene i Norge var aldri utfordret, og de involverte kunne jobbe med kjente arbeidsoppgaver. Mange beskrev en opplevelse av dugnadsånd og en stor vilje til å samarbeide på tvers av avdelinger.

Trolig fikk psykososialt personell, politi og organiserte frivillige nye og mer utfordrende oppgaver enn i deres daglige virke. Det at de mestret disse utfordringene, kan ha ført til større tro på fremtidig mestring. Mange av de sykehusansatte beskrev at arbeidsoppgavene stort sett var slik de er vant til, men at pågangen av pasienter var større.

I den ujusterte regresjonsanalysen hadde kjønn (kvinne) sammenheng med økt tro på fremtidig mestring, men denne sammenhengen forsvant i den justerte analysen. Forhold knyttet til selve hendelsen og rolleklarhet ser dermed ut til å ha større sammenheng med fremtidstro på mestring enn kjønn.

Vi kan ikke gi noen sikker forklaring på kjønnsforskjellene, blant annet fordi det er en del forskjeller i rekrutteringen, idet det var yrkesgrupper med en høy andel menn som var utsatt for de største farene. 
Opplevd støtte fra arbeidsgiver hadde ingen signifikant sammenheng med tro på fremtidig mestring. Det finnes flere mulige forklaringer på dette. Vi slo sammen ulike tiltak, som for eksempel debrifing, møter som markerte overganger og sosiale samlinger. Disse møtene vil i form og innhold ha ulikt søkelys, og alle er ikke ment for å bearbeide erfaringer og opplevelser.

Sosial st $\varnothing t t e$, ikke minst fra arbeidsgiver, er viktig etter store belastninger. Kritikken mot politiet har nok for mange polititjenestepersoner blitt en ekstra belastning. Forskning har vist at støtte etter alvorlige hendelser kan gi mindre posttraumatisk stress (14). Utfallsmålet i artikkelen var tro på fremtidig mestring og ikke PTSD.

\section{Styrker ved studien}

Vi unders $\varnothing$ kte opplevelser etter en virkelig hendelse og sammenliknet ulike profesjonelle grupper som arbeidet med samme hendelse. Svarprosenten var moderat til høy, hvilket representerer en styrke sammenliknet med tilsvarende unders $\emptyset$ kelser.

Resultatene fra brann- og redningsetaten kan generaliseres fordi det var høy svarprosent for denne gruppen. De representerer trolig en mer homogen gruppe når det gjelder arbeidsoppgaver, da de jobbet på skadestedene og direkte med redning. Innsatspersonellet i de andre gruppene hadde trolig mer sammensatte oppgaver (operativt, behandling, kontor og så videre).

Vi må være mer forsiktige med å generalisere resultatene for gruppene med lavere svarprosent. Deltakerne i disse gruppene representerte også ulike yrker og har dermed hatt mer varierte oppgaver. Det er en styrke at vi har underbygd tanker om mestring med kommentarer fra respondentene.

\section{Svakheter ved studien}

Resultater baserer seg på den subjektive opplevelse av hendelsen - slik de involverte vurderte den

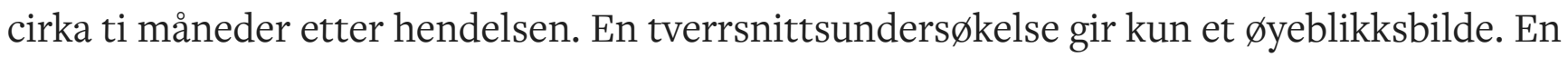
terroraksjon, eller andre store hendelser, skjer uten forvarsel. Det er også mulig at grupper som var spesielt eksponert, svarte på spørreskjemaet i mindre grad.

Unders $\varnothing$ kelsen er basert på selvrapportering, og intervjuer kunne gitt mer informasjon. Det er en svakhet at vi ikke har bedre mål på økt mestring etter hendelsen. Grunnen er at vi ikke var forberedt på at vi ville finne en så positiv sammenheng da vi designet studien. Vi mener imidlertid at vårt mål er tilstrekkelig til å ha dekning for hovedpoenget vårt om at innsatspersonellet har vokst på de krevende oppgavene.

Vi mener også at vi kan påvise noen faktorer som er forbundet med økt mestringsopplevelse. Det

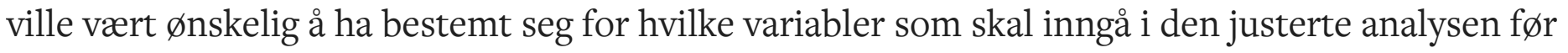
vi utførte den. Siden vi ikke tidligere så det potensialet som kom ut av studien, måtte vi velge analysene senere. Vi mener imidlertid at de benyttede variablene er relevante. 


\section{Kliniske implikasjoner}

Selv om øvelse er viktig, gir virkelige hendelser en læringsmulighet man ikke kan oppnå teoretisk eller gjennom øvelser. En naturlig lederoppgave vil være å sikre oppfølging og st øtte av innsatspersonell etter alvorlige hendelser. Slik oppfølging og st $\varnothing t t e$ kan styrke opplevelsen av mestring og samarbeid.

\section{«Selv om øvelse er viktig, gir virkelige hendelser en læringsmulighet man ikke kan oppnå teoretisk eller gjennom $\emptyset$ velser.»}

\section{Konklusjon}

Alle innsatsgruppene rapporterte at de hadde større tro på egen mestring i liknende situasjoner etter terrorhandlingene 22. juli 2011. Flere faktorer, som at de startet opp innsatsen 22. juli, ble eksponert for flere potensielt belastende vitneopplevelser samt opplevde rolleklarhet og hadde lavere alder, var forbundet med $\varnothing \mathrm{kt}$ tro på fremtidig mestring.

Fremtidig forskning bør unders $\varnothing$ ke effekten av omsorgsfull ledelse, opplevelse av samarbeid og stolthet over egen og andres innsats.

\section{Referanser}

1. NOU 2012: 14. Rapport fra 22. juli-kommisjonen. Oslo: Departementenes servicesenter, Informasjonsforvaltning; 2012.

2. Hartley TA, Violanti JM, Sarkisian K, Andrew ME, Burchfiel CM. PTSD symptoms among police officers: Associations with frequency, recency, and types of traumatic events. International Journal of Emergency Mental Health and Human Resilience. 2013;15(4):241-54.

3. Skogstad M, Skorstad M, Lie A, Conradi HS, Heir T, Weisæth L. Work-related posttraumatic stress disorder. Occupational Medicine. 2013;63(3):175-82.

DOI: $10.1093 /$ occmed/kqtoo3.

4. Perrin MA, DiGrande L, Wheeler K, Thorpe L, Farfel M, Brackbill R. Differences in PTSD prevalence and associated risk factors among World Trade Center disaster rescue and recovery workers. American Journal of Psychiatry. 2007;164(9):1385-94.

5. Whalley MG, Brewin CR. Mental health following terrorist attacks. British Journal of Psychiatry. 2007;190:94-6. DOI: 10.1192/bjp.bp.106.026427.

6. Skogstad L, Heir T, Hauff E, Ekeberg $\varnothing$. Post-traumatic stress among rescue workers after terror attacks in Norway. Occupational Medicine. 2016;66(7):528-35. 
DOI: $10.1093 /$ occmed/kqwo63.

7. Gjerland A, Pedersen MJB, Ekeberg $\varnothing$, Skogstad L. Sick-leave and help seeking among rescue workers after the terror attacks in Norway, 2011. International Journal of Emergency Medicine. August. 2015;8:31.

8. Blix I, Hansen MB, Birkeland MS, Nissen A, Heir T. Posttraumatic growth, posttraumatic stress and psychological adjustment in the aftermath of the 2011 Oslo bombing attack. Health and Quality of Life Outcomes, 2013;11:160. DOI: 10.1186/1477-7525-11-160.

9. Dyregrov A, Dyregrov K. Positiv vekst etter livskriser - implikasjoner for praksis. Tidsskrift for Norsk Psykologforening. 2011;48(9):873-7.

10. Brockhouse R, Msetfi RM, Cohen K, Joseph S. Vicarious exposure to trauma and growth in therapists: The moderation effects of sense of coherence, organizational support, and empathy. Journal of Traumatic Stress. 2011;24(6):735-42. DOI: 10.1002/jts.20704.

11. Leykin D, Lahad M, Bonneh N. Posttraumatic symptoms and posttraumatic growth of Israeli firefighters at one month following the Carmel fire disaster. Psychiatry Journal. 2013; article ID 274121. DOI: $10.1155 / 2013 / 274121$.

12. Chopko BA. Posttraumatic distress and growth: an empirical study of police officers American Journal of Psychotherapy. 2010;64(1):55-72.

13. Thoresen S. Mestring og stress hos innsatspersonell og journalister mobilisert til Tsunamikatastrofen. Oslo: Nasjonalt kunnskapssenter om vold og traumatisk stress; 2007. Rapport nr. 2/2007.

14. Skogstad M, Skorstad M, Lie A, Conradi HS, Lau B, Heir T, et al. Posttraumatisk stresslidelse (PTSD) og arbeidslivet. Oslo. Nasjonalt kunnskapssenter om vold og traumatisk stress og Statens arbeidsmiljøinstitutt; 2011. STAMI- rapport; årgang 12, nr. 3 .

15. Pedersen MJB, Gjerland A, Rund BR, Ekeberg $\varnothing$, Skogstad L. Emergency preparedness and role clarity among rescue workers during the terror attacks in Norway July 22, 2011. PLoS One. 2016;11(6). DOI: 10.1371/journal.pone.0156536.

16. Janacsek K, Fiser J, Nemeth D. The best time to acquire new skills: age-related differences in implicit sequence learning across the human lifespan. Developmental science. 2012;15(4):496505. DOI: $10.1111 / \mathrm{j} \cdot 1467-7687.2012 .01150 . x$. 
